\title{
SPEECH ACTS PROFICIENCY OF JUNIOR HIGH SCHOOL ENGLISH TEACHERS
}

\author{
Kamarudin \\ IKIP Mataram, kamarudin.ntbe@gmail.com) \\ Lume \\ Universitas Nahdlatul Wathan, lumempd620@gmail.com
}

\begin{abstract}
Junior High School English teachers involved in this study taught English' speech acts at a Junior High School, where the materials taught include high level of spoken English. Thus, the English teachers need to be proficient in this particular skill. As professional educators, the teachers must have professional competencies, particularly a good comprehension of the materials. Speech act constitutes spoken English, which is generally taught in Junior High School. Developing communication competence in English is the main purpose of English teaching in Junior High School. This descriptive qualitative research aims to describe a phenomenon: the ability of speech acts of Junior High School teachers. This knowledge comprises of several categories, namely the ability to define of speech acts, to identify speech acts conversations and to figure out speech act utterances. Drawing on the data garnered through the interviews, it was unveiled that most of the Junior High School English teachers could respond the given questions pertinent to speech acts. They could define the meaning of speech acts, identify the speech act conversations and figure out the speech act utterances. This study demonstrates that the proficiency level of the Junior High School English teachers is very good as they comprehend teaching materials and have good pedagogical skills.
\end{abstract}

Keywords: Speech Acts, Proficiency, Junior High School Teacher.

\section{INTRODUCTION}

Finocchiaro (1989) says that a teacher is considered as one of the important keys to successful language learning. Moreover, s/he 
is also a person who is actually involved in the teaching and learning process". Definitely, someone who has consciously chosen a professional job as a teacher can be said respectfully that $\mathrm{s} / \mathrm{he}$ was proposing his/her self to be a guide for his/her students to make their life better. It can be said that that teacher responsible on his/her students' education.

Depdiknas mentioned that there were 3 objectives of teaching English at Junior High School. First is to develop communicative competence both spoken and written, to achieve functional literacy level. Functional level is communicating in spoken or written to accomplish daily need such as reading newspaper, manual and instruction. Second is to grow the awareness of meaning and the advantage of English as international language to increase nation competitiveness in global society. The third is to develop understanding of the relation between language and culture as well as extending cultural knowledge (Depdiknas, 2004).

In Standar ISI (BNSP, 2010) for English, the material for Junior High School is about English text types that are divided into three; genre, speech acts (transactional \& interpersonal conversations) and short functional text. Genre covers narrative, descriptive, recount, news item etc. Speech acts covers greetings, leave taking, giving opinion, giving command etc., while short functional text covers pamphlet, banner, invitation, advertisement etc. Genres and short functional texts are taught in all skills, but speech act is just taught in listening and speaking skills (spoken cycle). Therefore, speech acts are highly taught in Junior High School level.

Junior High School teachers should master and understand speech acts well as the teaching materials. But in fact the greater attention is put to genre and short functional text, while speech acts get less attention. Teachers rarely teach speech acts or just skip some of them, because of many reasons, and they usually underestimate it. The expressions used in speech acts are the simple and daily expressions for various usages, so there is a tendency to consider it below other materials.

Whereas, speech acts are very important for students of English as a foreign language, especially in Junior High School 
level, the students will learn basic expressions/utterances of daily conversations for their speaking skill whether it is transactional or interpersonal. In this level, students are firstly taught about the various kinds of speech acts. Hence, they may get difficulties in understanding them since the speech acts in Junior High School are so vary.

Therefore, investigating speech acts proficiency of English teachers in Junior High School level is necessary, particularly in SMPN 2 Mataram (State Junior High School No. 2 Mataram). The following research questions guide the whole parts of this study.

1. How did the English teachers of SMPN No. 2 Mataram define speech acts?

2. How did the English teachers of SMPN No. 2 Mataram identify speech acts conversations?

3. How did the English teachers of SMPN No. 2 Mataram figure out speech acts utterances?

\section{LITERATURE REVIEW}

\section{A. Teachers as Primary Role Model}

Teachers use many metaphors to describe what they do. Sometimes they are like actors because they are on the stage'. They are also like orchestral conductors because they direct conversation and set the tone'. Yet, they are like gardeners because they plant the seed and then watch them grow'. The ranges of images above indicate the range of view about teachers' profession. But, in simple words, "A teacher is someone who gives knowledge to the students". (Susarno, 2007, 146).

In society, teacher is considered as honorable person, they sure that it is teacher who can educate their children. By this belief, teachers hold a huge duty and great responsibility.

The roles of the teacher also vary; teacher can be a facilitator, controller, organizer, assessor, prompter, participant, resource, tutor, and observer and teaching aid and the roles of the teachers have been considerably expanded and include needs analyst, curriculum developer, materials developer, counselor, mentor, team member, researcher and professional. (Harmer, 2001; Richards \& Lockhart, 1994). 


\section{B. Speech Acts Knowledge}

Philosophers assume that statement can only describe something or state facts, which is true or false. But, grammarians find that not all sentences are used to make statement, but also questions, commands, exclamations or wishes (Austin, 1962). Moreover, Austin, in his book 'How to Do Things with Words' (1962), stated that language is a kind of social activity rather than stating truly or falsely. He showed that words are not only something we use to say things. We also use them to do things, that's why "performative" is Austin's term for language with the primary function of doing something. From this assumption, the term 'speech act' is introduced. The speech acts theory basically concerns on what people do with language with the function of language.

Speech acts play an important role in effective communication and are important components of sociolinguistics competence. A speech act is defined as a minimal functional unit in human communication (Searle, 1969: 21). Philosophers like Austin (1962) and Searle (1969) offered an assumption that the minimal units of human communication are not linguistics expressions, but rather the performance of certain kinds of acts, such as making statements, asking questions, giving directions, apologizing, thanking, greeting, request, complaint and so on. The ranges kinds of speech acts prove that speech acts are important in effective human communication.

In general, speech acts are acts of communication. To communicate is to express a certain attitude, and the type of speech act being performed corresponds to the type of attitude being expressed. For example, a statement expresses a belief, a request expresses a desire, and an apology expresses regret. As an act of communication, a speech act succeeds if the audience identifies, in accordance with speaker's intention, the attitude being expressed.

\section{Speech Acts Utterances}

When a sentence is uttered, the problem is sometimes the speaker intent and the sentence meaning is not always the same. Speaker intent may be more or less, or actually the opposite, of sentence meaning (as in sarcasm). Seeing that, Austin (1962) argued that utterances have three kinds of meaning. He believed that 
studying words or sentences (Locutionary acts) outside of a social context tells us little about communication (Illocutionary acts) or its effect on an audience (Perlocutionary acts).

\section{Locutionary Meaning}

Locutionary meaning is a literal meaning or propositional meaning of an utterance. It produces a meaningful linguistics expression, the meaning of what a speaker says. If someone says, "It is hot in here", and only means this and nothing beyond it, then his concern is just the high/hot temperature in the room. This meaning is explicit, stated fully and clearly.

\section{Illocutionary Meaning}

The second meaning is illocutionary which has to do with the social function of an utterance. Searle (1969) claimed the illocutionary act is "the minimal complete unit of human linguistic communication. Whenever we talk or write to each other, we are performing illocutionary acts". Illocutionary acts are performed with intentionally (on purpose). The social function of 'It's hot in here' could be:

- An indirect request for someone to open the window.

- An indirect refusal to close the window.

- A complaint implying that someone should know better than to keep the windows closed (expressed emphatically).

See that an utterance can have three different implicit meaning; request, refusal or complain. These meaning are not explicitly stated. Illocutionary meaning is successfully understood if the speaker's intention is recognized by the hearer.

\section{Perlocutionary Meaning}

Perlocutionary meaning deals with the result or effect that is produced by an utterance. In other words, it is hearer's behavioral response to the meaning of the utterance, not necessarily a physical or verbal response. For example, warning hearer of danger, persuading hearer to an pinion, getting hearer to do something, a hint, a request, a command etc. Thus, if the previous utterance leads to the opening of a window, then the utterance has had its perlocutionary or intended effect. This effect is intended by the speaker on the audience/hearer. 'It's hot in here' could result in someone opening the windows. Other examples:

- Give me an apple. 
Locutionary act: the utterance itself.

Illocutionary act: Request, command.

Perlocutionary act (presumably): $\mathrm{H}$ passes $\mathrm{S}$ an apple.

- I promise to beat you blue and green if you forget to buy bread tonight.

Locutionary act:

Illocutionary act: threat,

Perlocutionary act (presumably).

\section{Speech Acts Classification}

A few years later in 1969, another scholar called Searle worked more on speech acts and assigned functions to them. He then classified them into a small set of functions. The five categories are:

Representatives are those kinds of speech acts that state what the speaker believes to be the case or not which commit the speaker to the truth of the expressed proposition, such as statements of fact, assertations, claims, reports and conclusions.

Directives are those kinds of speech acts through which the speaker gets the addressee to do something. A request is being made so that the addressee will do or stop doing something such as commands, orders, requests, questions and suggestions.

Commissives re those kinds of speech acts that speakers use to commit themselves to some future action such as promises, threats, refusal, offers, etc.

Expressive are those kinds of speech acts that state what the speaker feels. They express various psychological states such as likes, dislikes, joy, sorrow, apologies, complaint, apologize, congrats, welcome, thanks, etc.

Declaratives (Austin calls these performatives) are those kinds of speech acts through that change the world through their utterances and bring about a new state of being (decrees, declarations). For example, excommunicating, declaring war, christening, firing from employment, etc.

\section{E. Conversations in Language Teaching}

"Conversation is the interchange of ideas; it is the willingness to communicate thought on all subjects, personal and universal, 
and in turn to listen to the sentiments of others regarding the ideas advanced" (Conklin, 2009:12).

Many studies occurred to classify the function of speaking in social life. Brown and Yule (1983) point out that speaking in human interaction has two functions namely as an interactional and transactional. The interactional function of speaking are concerned to establish and maintain relations. While, dealing with the exchange of information is the term of transactional function. Transactional emphasizes on the 'content', and interactional tends to express social relations and personal attitudes. In Standar ISI for English, those functions of speaking are known as the term transactional conversation and interpersonal conversation.

\section{RESEARCH METHOD}

This research used descriptive qualitative method. It was used due to describing speech acts profiency of Junior High School teaachers in terms of the ability to define speech acts, identify the conversations and utterances of speech acts.

Briefly defined, "the term qualitative research is research that is based on descriptive data that does not make (regular) use of statistical procedures", (Mackey and Gas, 2005: 162). It describes phenomena in words instead of numbers or measures. So, "qualitative research is concerned with subjective opinions, experiences and feeling of the participants' views of the situation being studied."

This study was held in SMPN 2 Mataram. This qualitative research took place in natural setting. Thus, the writer as qualitative researcher went to the site (office) of the participant to conduct the research. This enabled the writer to develop a level of detail about the teachers and to be highly involved in actual experiences of the teachers.

There were two teachers selected as the subjects. These teachers were taken based on their teaching experiences. The first teacher was less experienced teacher, he was newly employed in the school, he had little teaching experience, this first teacher was called 'teacher A'. The second teacher was the opposite of the first one; this teacher was more experienced teacher. He had taught for 
longtime and richly experienced; called 'teacher B'. This was done under the consideration of knowing the ability of teacher of less experienced and more experienced one.

The data of this study was utterances, propositions and expressions spoken/given by the teachers during interview sessions which are transcribed into written form. The sources of the data were two Junior High School teachers in SMPN 2 Mataram.

In qualitative research, the researcher is the key instrument. To collect the data, the writer used semi structured interview. This interview included recording and note taking.

The interview was held several times until adequate data gathered. These interviews were conducted informally in pleasant situation. The teachers did not feel under pressure so the data gathered was fair and pure.

The data was analyzed inductively, in words rather than in numbers. Qualitative research is fundamentally interpretive. This means that the researcher makes an interpretation of the data. The data are analyzed based on the following steps (Creswell, ___:218):

1. Organize and prepare the data for analysis. This involves transcribing interviews, optically scanning material, or sorting and arranging the data into different types depending on the sources of information. Qualitative research works with a wide range of data including recorded interviews. During data processing most data are transformed into a textual form (for example, interview recording are transcribed).

2. Read through all the data. A first general step is to obtain a general sense of the information and to reflect on its overall meaning.

3. Use the coding process to generate a description of the subjects as well as categories or themes for analysis. Description involves a detailed rendering of information about subjects in a setting. Then, use the coding to generate a small number of themes or categories. These themes are the ones that appear as major findings in qualitative studies, they should be supported by diverse quotations and specific evidence.

4. Advance how the description and themes will be represented in the qualitative narrative. The writer will use a narrative 
passage to convey the findings of the analysis. This may be a discussion of several themes (complete with sub-themes, specific illustrations, multiple perspectives from individuals, and quaotations), or a discussion with interconnecting themes.

5. A final step in data analysis involves making an interpretation or meaning of the data to find out the answers of research questions. This interpretation can be the findings with information gleaned from the literature or extant theories.

\section{FINDINGS AND DISCUSSION}

\section{The Ability to Define Speech Acts}

The ability to define speech acts was subdivided into four parts, which were the ability to identify the English text types, the ability to define speech acts, the ability to mention the example of speech acts and the ability to identify the characteristics of speech acts in Junior High School.

\section{A. Identifying the English Text Types}

The ability to identify the English text types was the teachers' knowledge of English materials in Junior High School which cover genres, short functional texts and speech acts (transactional and interpersonal conversations). It's so important that teachers must know the area and limitation of their teaching materials as stated in Standard Isi. Some teachers often get confused in identifying their English teaching materials, they are wrong in grouping them into the right clusters.

\section{Teachers A}

Ketika anda mengajar, materi apa saja yang biasanya anda sampaikan?

$\boldsymbol{R}$

(When you teach, what materials do you usually deliver?)

Ya sesuai dengan silabus dan RPP yang telah dibuat.

$\boldsymbol{A M}$ (The materials are agreeable with the syllabus and the RPP which have been made.)

$\boldsymbol{A F}$ Iya sama, sesuai silabus dan RPP. (Yes, I think so. It's suitable with the syllabus and RPP.) 
Kamarudin \& Lume, Speech Acts Proficiency...

(1): Teachers A answered that the materials they teach are based on the syllabus and lesson plan. They just follow what is stated in syllabus. Actually, this step is wrong; teachers should compose the materials based on standar isi or SKKD, because syllabus or lesson plan can be false.

\section{Teacher B}

$\mathbf{R} \quad L a l u$ materi yang biasanya anda sampaikan ketika mengajar itu apa saja? Tadi kan bapak menyinggung masalab SI, tentunya bapak mengerti materi untuk SMP!

(When you teach, what are materials usually you deliver? You had risen about SI, so of course you understand the material for SMP!)

BM baik listening, speaking, reading maupun writing, setelab saya membaca SKKD itu ya, ternyata yang di ajarkan itu, eee... yang bapak ingat ya, ada namanya transactional text, interpersonal text, ada functional text, ada monologue text. Jadi hanya berkisar pada materi itu. Contoh transactional dan interpersonal text adalah pengajaran dialog-dialog, untuk speaking dan listening juga bisa. Kalo functional text seperti bagaimana caranya membuat surat undangan, bagaimana mengundang seseorang, baik written maupun spoken. Jadi begitu. Kalo monologue text ditingkat SLTP itu ada 5, yang kita sebut dengan genre itu, ada narrative, descriptive, procedure, recount and report. Jadi ada 5. Nah... itu kita kembangkan, bagaimana cara mengembangkannya, kalo dijelaskan 1 tahun tidak cukup. Gitu...

Whether it is listening, speaking, reading or writing, after I read SKKD, evidently the materials is eee... if I remember it well, there are transactional text, interpersonal text, functional text and monologue text. So it is just around that. The example of transactional and interpersonal text is the teaching of dialogues, for speaking and listening. The example of functional text is such as how to create an invitation, how to invite someone, whether written or spoken. There are 5 monologue texts in SLTP, we use to call the as genre. They are narrative, descriptive, procedure, recount and 
report. We should develop all those materials, how to develop it, 1 year explanation is never enough.)

(2): BM stated that the materials he teaches are based on SKKD for the four English skills. The materials cover transactional interpersonal texts, functional text and monologue text (genre), BM even able to mention the example of each. BM also knew well that transactional \& interpersonal are the teaching of dialogues for listening and speaking skills.

\section{Teachers A}

R Di dalam Standar Isi untuk Mapel Bhs. Inggris, materi pelajarannya mencakup "English text types", yang dibagi menjadi 3 jenis materi, bisakah anda menyebutkan jenis-jenis English text types tersebut? (In Standar Isi for English, the teaching materials cover "English text types", which has been divided into three types. Can you mention the English text types?)

AM Writing, reading, listening itu y? (Writing, reading, listening?)

$\mathbf{R}$ Ob bukan, itu kan skills pak, ini English text types.

(Oh no, they are not. Those are skills Sir, I mean English text types.)

AM Descriptive, recount, narrative...

(Descriptive, recount, narrative...)

AF Report...

(Report...)

AM Lho... lebih dari 3, bukan itu berarti (terlihat bingung).

(Ow... it's more than three. It isn't) (looking confuse).

$\mathbf{R} L a l u$, menurut bapak, jenis-jenis text itu yang mana? Ada berapa?

(And then, in your opinion, what is mean by English text types? How many?)

AM Kalo jenis text itu banyak menurut saya, lebih dari 3, ada recount, descriptive, narrative, report... nah itu kan udah lebih dari 3.

(In my opinion, there are many kinds of text, it's more than three. There are recount, descriptive, narrative and report, nah it's more than three, right?) 
Kamarudin \& Lume, Speech Acts Proficiency...

(3): It seems that teachers A do not know anything about "English text types", moreover AM could not differentiate between English materials and English skills. Later, they mentioned that English text types are descriptive, recount, narrative, report etc, teachers A tought that English text types is genres. Those answers do not match as stated the references in the background of the study about English text types in Standar Isi.

\section{Teacher B}

R Untuk Mapel Bhs. Inggris, materi pelajarannya mencakup

"English text types". Apa saja materi yang tercakup dalam English text types tersebut?

(In Standar Isi for English, the teaching materials cover "English text types". Can you mention the English text types?)

BM $000 .$. English text types $y$ ? Ehm ... ya seperti yang saya jelaskan tadi, transactional and interpersonal text, functional text, terus monologue text atau bisa disebut genre.

(Ooo... English text types? Ehm... just like what I said before, transactional and interpersonal text, functional text, and then monologue text or we use to call it as genre.)

(4): Actually from transcript (2), it is clear that BM knew well about English text types, here BM just strengthen his statements.

In conclusion, teacher $\mathrm{B}$ is more knowledgeable than teachers A, because teacher B was able to identify the English text types and mention the example of each text types correctly. While teachers A could not identify what English text types are.

\section{The Ability to Identify Speech Acts Conversations}

\section{A. Mentioning Kinds of Speech Acts Conversations}

Here are two kinds of speech acts conversation namely transactional conversation and interpersonal conversation.

\section{Teachers A}

R Ketika speech acts di aplikasikan ke dalam sebuah

percakapan, dapat di bedakan menjadi dua jenis percakapan, apa sajakah itu?

(When speech act is applied into a conversation, it can be divided into two types, what are they?) 
AF Transactional dan interpersonal.

(Transactional dan interpersonal.

$\mathbf{R} \quad$ Apa yang anda ketahui tentang dua jenis percakapan tersebut?

Beri contoh masing-masing!

What do you know about those two conversations? Give example in each!)

AM Kalo interpersonal itu sifatnya basa-basi, kalo transactional itu ya jelas gitu loh, posisinya jelas. Misalnya gini, "good morning, Sir" itu kan basa-basi, menyapa orang itu termasuk interpersonal. Kalo dalam bahasa Madura "Ngereng lengghi!" Tapi kalo transactional "take me a glass of water please!" itu kan masuk transactional. Kalo kebalik maaf ya? (Interpersonal conversation is about courteousness, but transactional is clear, I mean the position is clear. For example "good morning, Sir" is courteous utterance, right? So greeting is interpersonal, in Madurese, "Ngereng lengghi!" But transactional, for example "take me a glass of water please!" I'm sorry if they are overturned.)

AF Sama seperti yang tadi, kalo transactional itu jelas, kalo interpersonal cenderung basa-basi, "good morning", "hello", "how are you?" Tapi kalo transactional "may I borrow your pencil?"

(Same with the first opinion, transactional is clear, but interpersonal tends to make courteous utterances such as "good morning", "hello", "how are you?" But "may I borrow your pencil?” is transactional.)

(1): from the script, teachers A mentioned the speech acts conversations correctly. They defined interpersonal as courtesy and transactional as clear position of conversations, but the definition of transactional conversation is less precise and incorrect. Nevertheless, they could give the examples of speech acts and utterances of both transactional and interpersonal conversatios.

\section{Teacher B}

$\mathbf{R}$ Ketika speech acts di aplikasikan ke dalam percakapan, dapat di bedakan menjadi dua jenis percakapan, apa sajakah itu?

(When speech act is applied into a conversation, it 
Kamarudin \& Lume, Speech Acts Proficiency...

can be divided into two types, what are they?)

BM Hmm... Tergantung konteks dialognya bagaimana, sebenarnya ada dua jenis, interpersonal and interpersonal texts itu y maksudnya juga bisa buat percakapan.

(Hmm... it depends on the context of the dialogue, actually there are two types, interpersonal and interpersonal texts, they are also can be used for the term conversation.)

$\mathbf{R}$ Apa yang anda ketabui tentang dua jenis percakapan tersebut? Beri contoh masing-masing!

(What do you know about those two conversations? Give example in each!)

BM Interpersonal adalah percakapan untuk bersosialisasi, istilahnya basa-basi lah untuk memulai suatu percakapan. Nah kalau transactional inti dari suatu percakapn, maksud dan tujuan di adakannya percakapan tersebut, maksud dan tujuannya jelas, ndak panjang lebar kayak transactional. Contoh interpersonal itu greeting, berkenalan juga bisa, "hi", "how are you?" itu kan cuma sekedar menyapa, keakraban, bisa dikatakan interpersonal itu kesopanan, sopan santun dalam memulai suatu percakapan. Kalo transactional ya banyak contohnya, eee... asking for opinion, information, asking for help, itu termasuk transactional.

(Interpersonal is kind of conversation used to socialize, courtesy to start a conversation. Transactional is the core of a conversation, the clear intention and the aim of the conversation, it's not too extensive like transactional. The example of interpersonal is greeting and introduction, "hi", "how are you?" these expressions are just say hello, familiarity, and one might say that interpersonal is about politeness, good manners in starting a conversation. There are many example of conversational, eee... asking for opinion, information, asking for help.) 
(2): BM also mentioned the conversations of speech acts correctly and BM could give the correct and complete definition of transactional and interpersonal conversations. The example of speech acts and utterances of both conversations are also correct. In conclusion, teachers $\mathrm{A}$ and teacher $\mathrm{B}$ are knowledgeable because both of them are able to mention the kinds of speech acts conversations, gave the example of speech acts and utterances of both conversations.

\section{B. Stating the Differences between Transactional \& Interpersonal Conversations}

\section{Teachers A}

R Suatu percakapan yang bertujuan untuk bertransaksi/jual beli atau tukar menukar informasi, menurut anda termasuk yang mana?

(A conversation aims to have transaction/trade or swap information. Is it transactional or interpersonal?)

AM Transactional.

(Transactional.)

$\mathbf{R} \quad$ Kalau percakapan di balte bis misalnya, antara dua orang yang tidak saling mengenal, tujuannya untuk. membangun bubungan sosial dan basa basi termasuk apa?

(A conversation at bus stop between two people who don't know each other and the intention id just to establish social relationship and courteousness. Is it transactional or interpersonal?)

AF Interpersonal.

(Interpersonal.)

R Suatu percakapan, topiknya bebas, panjang lebar, dan hasilnya tidak dapat diprediksi, termasuk apa?

(A conversation, the topic is free, extensive and has unpredictable result. Is it transactional or interpersonal?)

AF $Y a$ interpersonal juga.

(It is interpersonal too.)

R Mungkinkah dalam sebuah percakapan mengandung transactional and interpersonal conversations sekaligus? Misalnya? (Is it impossible that in one conversation contains both transactional and interpersonal conversations? Could you 
Kamarudin \& Lume, Speech Acts Proficiency...

\begin{tabular}{ll}
\hline AF & $\begin{array}{l}\text { give me example?) } \\
\text { Mungkin... } \\
\text { (Maybe...) }\end{array}$ \\
BM & $\begin{array}{l}\text { Bukan mungkin lagi, tapi pasti. Seperti contoh yang tadi, awalnya } \\
\text { memang basa-basi, setelah itu lari ke inti. } \\
\text { (It is impossible and definitely yes. Like the previous } \\
\text { example, in the beginning is courteousness and ran } \\
\text { forward to the point.) }\end{array}$
\end{tabular}

(1): Teachers A could answer all the questions correctly, so automatically the also could differentiate between transactional and interpersonal conversations.

\section{Teacher B}

R Suatu percakapan, topiknya bebas, panjang lebar, dan hasilnya tidak dapat diprediksi, termasuk apa?

(A conversation, the topic is free, extensive and has unpredictable result. Is it transactional or interpersonal?)

BM Kalo topiknya bebas dan panjang lebar itu interpersonal. Untuke pengajarannya sendiri sebenarnya tidak bisa dipisab antara transactional dan interpersonal, jadi dalam 1 dialog, bagian pembuka itu transactional, tidak mungkin orang berbicara itu langsung masuk ke pokok pembicaraan, mesti ada basa-basinya dulu, lalu bagain selanjutnya itulah yang transactional, maksud inti dari setiap dialog, ada jual beli, minta informasi misalnya. (If the topic is free and extensive, it is interpersonal. For the teaching itself, it can not be separated between transactional \& interpersonal, so in one dialogue, the opening is transactional, it is impossible for people to talk directly into the point, there must be courtesy, then the next part is transactional, the point of every dialogue, such as trade, asking for information)

(2): Actually at transcript (12), BM has already clearly defined and stated the differences between transactional and interpersonal, so here the researcher didn't need to give the complete questions like transcript (13). BM has good comprehension of transactional and interpersonal conversations.

\section{A. The Ability to Identify Speech Acts Utterances}

There are 41 speech acts in Junior High School; every speech acts has some utterances which are usually unclear or 
confusing. The ability to identify speech acts utterances is divided into two ability; they are describing the differences of speech acts in every grade and identify the utterances of speech acts. There are some types of questions; the first one is teachers had to differentiate the differences of utterance between two similar speech acts, the second one is teachers were asked directly the utterances of certain speech acts, and the third is teachers had to identify the speech acts of the utterances given.

\section{Greetings}

$\mathbf{R} \quad$ Ada dua jenis greetings, yaitu menyapa orang yang belum dikenal dan menyapa orang yang sudah dikenal, menurut anda apa perbedaan dari keduanya? (dari segi ungkapan)

(There are two types of greetings. They are greeting a stranger and greeting people who are already known. In your opinion, what is the difference? (In terms of expression))

\section{Teacher A}

AF kalo ungkapan untuk orang yang dikenal, contobnya begini "how are you?" tp buat yang belum dikenal, biasanya menggunakan "how do you do?" seperti itu.

(The example of greet people who are already known is "how are you?" for greeting stranger, usually we use "how do you do?")

\section{Teacher B}

BM kalo untuk orang yang dikenal, ungkapannya seperti ini "how are you?", "Hi", ato langsung menyebut namanya "Hi, Miss Sofi", tapi untuk orang yang belum dikenal, biasanya lebih sopan "how do you do?", jawabannya "how do you do" juga, seperti itu.

(The utterances for people who are already known are such as "how are you?", "Hi" or just call her name "Hi, Miss Sofi", but for stranger, usually it's more polite "how do you do?" and the answer is "how do you do?" too.)

\section{Introductions}

$\mathbf{R}$ Introduction juga ada dua jenis, yaitu memperkenalkan diri sendiri dan memperkenalkan orang lain, menurut anda apa 
Kamarudin \& Lume, Speech Acts Proficiency...

perbedaan dari keduanya? (dari segi ungkapan)

(There are also two types of introduction, introduce yourself and introduce others. In your opinion, what is the difference? (In terms of expression))

\section{Teacher A}

AF Yang memperkenalkan diri sendiri kepada orang lain, contohnya dimulai dengan kalimat "I would like to introduce my self, my name is..." kalo mengenalkan orang lain ya tinggal belakangnya aja diganti "I would like to introduce my friend, his name is..."

(The example of introducing yourself, it begins with the utterances "I would like to introduce my self, my name is..." if it is introducing others, just substitute the back part, for example "I would like to introduce my friend, his name is...")

\section{Teacher B}

BM kalo mengenalkan diri sendiri ya langsung saja, "my name is sofi", "I am sofi", kalo untuk yang lebih formal bisa menggunakan "I would like to introduce my self. My name is..." kalo memperkenalkan orang lain, sebenarnya prinsipnya sama cuma ada tambahan kayak "I would like to introduce my friend, his name is...", itu formal, kalo yang biasa seperti "this is doni"

(To introduce our self just directly say "my name is sofi", "I am sofi", for formal situation you can use "I would like to introduce my self. My name is...". To introduce other people, actually the principle is the sama but there is addition such as "I would like to introduce my friend, his name is...", that's for formal situation, for the informal is "this is doni")

\section{Asking for Clarification}

$\mathbf{R} \quad$ Meminta klarifikasi (ask for clarification) di ajarkan di kelas VII, apa saja contoh ungkapannya?

(Ask for clarification is taught in class VII, what are the examples of the utterances?)

\section{Teacher A}

\section{AF kalo meminta klarifikasi kan kita mengharapkan informasi,}


tapi kalo meminta klarifikasi, kita meminta penjelasan tentang informasi yang sudah ada. Seperti "is it right?"

(Asking for information means we expect the information, but asking for clarification, we ask for an explanation of the existing information such as "is it right?")

\section{Teacher B}

BM Meminta klarifikasi... prinsipnya sama seperti meminta informasi, sama-sama ingin mengetahui seseuatu, tapi kalau klarifikasi itu kita meminta penjelasan tentang informasi yang sudah diketahui, kalo meminta informasi kita benar-benar tidak. tabu. Ya kayak "is it right?" apa lagi ya...

(Asking for clarification... it's same with asking for information, it wants to know something, but clarification is when we want to get further explanation of known information, while asking for information is if we don't know anything. Such as "is it right?" what else?)

\section{Apology}

R "I do apologize for my mistakes" \& "Please accept my apology"

Termasuk ungkapan speech act apa?

"I do apologize for my mistakes" \& "Please accept my apology"

Teacher A

Including to which speech act are they?

AF meminta maaf.

Teacher B

(Apologizing.)

BM Meminta maaf.

(Apologize)

R "I do apologize for my mistakes" \& "Please accept my apology"

Termasuk ungkapan speech act apa?

In conclusion, both teacher A and teacher B are knowledgeable, because they are able to identify the utterances of speech acts. 
Kamarudin \& Lume, Speech Acts Proficiency...

\section{CONCLUSION AND IMPLICATION}

Based on the result of the study, it is conclude that the teacher A (less experienced teachers) was capable enough in defining speech acts; he could mention the example of speech acts and identify speech acts characteristics in Junior High School but he confused to identify the English text types. He also had low knowledge to identify speech acts conversations; he could mention kinds of speech acts conversations, but he was not able to state the differences between transactional \& interpersonal conversations and classifying speech acts into transactional \& interpersonal conversations. Teacher A was also quite capable to identify speech acts utterances.

Teacher B (more experienced teacher) was knowledgeable in defining speech acts. He also had good knowledge to identify speech acts conversations. He was quite capable to identify speech acts utterances. If the researcher had to compare the knowledge of teacher $\mathrm{A}$ and teacher $\mathrm{B}$, it is concluded that teacher B (more experienced teacher) was knowledgeable than teachers A (less experienced teachers). But overall, Junior High School teachers have good knowledge of speech acts. So, Junior High School teachers had already fulfilled the teacher professional competence and professional language teacher competence, because they comprehend the teaching materials and have good pedagogical skills

\section{REFERENCES}

Austin, J. L. (1962). How to Do Things with Words. Oxford: Oxford University Press.

Conklin, M. G. (2009). Conversation: What to Say and How to Say It. -: The Floating Press.

Creswell, J. M. (n.d.). Research Design: Qualitative, Quantitative and Mixed Methods Apptoaches. $2^{\text {nd }}$ Ed. -.

Departemen Pendidikan Nasional. (2004). Standar Kompetensi Mata Pelajaran Bahasa Inggris SMP dan MTs. Jakarta: Depdiknas. 
Finocchiaro, M. (1989). Some Facts about Language Teaching in the Elementary School: Teaching Children Foreign Language. New York: Mc Graw-Hill Book Company.

Gillian, B \& Yule, G. (1983). Discourse Analysis. Cambridge: Cambridge University Press.

Harmer, J. (2001). The Practice of English Language Teaching. 3rd Ed. England: Pearson Education Limited.

Alison, M., \& Gass, S. M. 2005. Second Language Research: Methodology and Research. London: Lawrence Erlbaum Associates, Inc.

John, S. (1969). Speech Acts: An Essay in the Philosophy of Language. Cambridge: Cmabridge University Press.

Susanto. (2007). Writing a Scientific Essay: A Guide for the Writing of an Article. Surabaya: Universitas Negeri Surabaya. 


\title{
A STUDY OF EFL STUDENTS' AWARENESS ON APOLOGY THROUGH CROSS CULTURAL LEARNING ACTIVITIES Ardiyani Widya Permatasaria
}

Sebelas Maret University, ardiyaniwidya@gmail.com

\section{Diah Kristina ${ }^{b}$}

Sebelas Maret University, Sumardic

Sebelas Maret University,

\begin{abstract}
This study aims to explore the kinds of cross-cultural learning activities contributing to EFL students' awareness on apology function, and how the process occurred in two different EFL universities in Indonesia. This mixed-method study collected the data through questionnaires and interviews. The quantitative data was obtained from six Indonesian EFL students using Discourse Completion Tasks Questionnaires (DCTQ), while the qualitative data was garnered from individual interviews carried out with six EFL students. The empirical evidence showed that there were group discussions and role plays used as cross cultural learning activities, which contributed to EFL students' awareness on apology functions. Then, there was apology strategies used in in applying those two learning activities. Another finding also showed that the students used many apology strategies; they were well aware of how to use adequate apology forms to meet the requirement of certain situations and relationships; and they felt the need for explaining and avoiding interpretation of their responses as an apology.
\end{abstract}

Keywords: EFL students, awareness on apology, cross cultural learning activities 
Permatasari, et al., $A$ Study of EFL ...

\section{INTRODUCTION}

There is a required course called Cross Cultural Understanding which is conducted to enhance students' overall English proficiency by focusing on developing students' writing, speaking, reading and listening skills (Zacharias, 2012). In English language teaching of English Department, Cross Cultural Understanding (CCU) course is a compulsory course in a four-year pre-service program of an English Department in the Faculty of Language and Literature, in Indonesia. On the other hand, problems arise from the lack of cross-cultural awareness, such as verbal communication, postures, mimics, another ways of behavior, and speech acts can cause miscommunication (Cakir, 2006).

In the pre-interview, the researcher has found informal findings that the participants are more aware of using the speech acts in the daily life communication. First case, a student who ever enrolled in student exchange when she was in her senior high school found that her classmates who comes from different nationalities did not know others cultures. Moreover, for saying sorry, she felt that their classmates did not really feel sorry for their mistakes for they did the same mistakes over again. For example, when they were joking and started to make stereotype by labeling their race. In this case, when she came back to Indonesia, she felt that implementing CCU based learning activity with speech act theory topic really helps to overcome similar problems she ever faced. Second case, a student who went abroad for vacation found that the degree of speech acts is different in each language, and it needs adjustments and familiarization. For apology forms he found quite difficult for his to adjust within the beginning. He used to say "sorry" a lot to people which is older than him. In fact, he knew that it is better to say "I do apologize". Thus, he felt that as EFL learners, we do not only have to acquire grammatical theories but also pragmatic theories in this case apology forms.

By noticing in the pre-interview and the topic selection, the researcher assumes that there are some significances of selecting the topic. First, there is a theoretical consideration that there is none of concrete data of this research for there are only theories about enhancing cross cultural understanding-based learning 
activities and the importance of implementing speech act awareness (Lado, 1963; Chastain, 1988). Moreover, for practical consideration the EFL students or learners' acquisition in how people act to certain situations, the way people speak and behave are enhanced. At last, the researcher curiosity is even deeper because of the lack of studies focusing on speech act awareness where English is a foreign language.

Some relevant studies conducted in the foreign language settings which focused on CCU based learning activity were firstly Zaharias, 2012 entitled EFL Students' Understanding of Their Multilingual English Identities and the findings were many of the participants negotiated their identities based on a core identity derived from their assumed first language culture. Then, Zayed, 2014 entitled Jordanian EFL teachers' and students' practice of speech acts in the classroom with the findings EFL teachers' and students had no proper practice of any of the speech acts although the teachers practiced the speech acts of greeting, request, and thanking better than the speech acts of apology and compliment and the students practiced the speech act of greeting better than the other speech acts. At last, Qorina Dwi (2012) conducted a study on realization of apology strategies by English Department Students of Pekalongan University who investigate the development strategies from the lowest to the highest semester students, and to explain how the pragmatic transfer interferes the apology strategies used by English Department students of Pekalongan University. The findings reveal that an explicit expression of apology, in particular, the strategy of expressing regret, is the most frequent apology strategy.

Studies focusing on CCU based learning activity in EFL context even remain scanty. Knowing that EFL contexts are merely varied with regard to the intensity of English learning (i.e. hours per week), the availability of teaching materials, the relative importance of English in the society, and the purpose of learning English (Block, 2007 as cited in Zacharias, 2012, p. 234). Thus, the need of a study focusing on enhancing speech act awareness through CCU based learning activities in EFL contexts where English is acquired in the institutional setting. 
Cross cultural Understanding for Indonesian EFL students is taught in English department as pre-requirement course. In general, Indonesian students have to pass certain courses to be able to take Cross Cultural Understanding course. Nonetheless, the teaching and learning situation in Indonesia focuses more on linguistic competence. As a result, in real-life situation, Indonesian students often fail to communicate effectively with same Indonesian students from various ethniticities or even foreigners using English in certain situations. To avoid misunderstanding between the speaker and the hearer and to achieve communication goal, specifically when the speaker and the hearer are from different cultures and ethnicities or countries is by knowing the meaning behind words. In this case, politeness plays a main role to avoid communication offense. The fact that there are many kinds of politeness concepts accross cultures in the world, studying apology functions and strategies through cross cultural learning activities will meet EFL students' needs in raising their awareness. This study may highlight two kinds of CCU learning activities and how these two learning activities play as a big role in raising EFL students' awareness on apology functions.

This study aims at explaining and providing evidence on to what extent CCU based learning activities contribute toward EFL students' awareness on apology functions. The result of the study aims at providing EFL learners or reasearchers or teachers with information that help to improve both competence: linguistic and pragmatic. At last, the study contributes to pragmatic-teaching in EFL research.

\section{LITERATURE REVIEW}

\section{a) CCU Based Learning Activity in ESL Context}

Researchers conducted some studies on CCU based learning activities in ESL context with some findings as below:

1. Mizne thesis project (1997) showed the solution of facing problems of ESL students toward lack of sociolinguistic competence which comes from lack of cross-cultural understanding of ESL students and leads to misunderstandings 
between the speech participants and then can cause serious breakdowns in communication by creating a teaching module (cross-cultural differences) which were proved to enhance ESL students' cultural and pragmatic awareness.

2. Youssef's research (2009) showed the students were better able to participate and express their ability and knowledge in the target language and had improved motivation by given crosscultural activity 'Sister School Project" and the implementation of self-evaluation.

3. Fadeeva and Kalinin (2012) showed that ESL students 'crosscultural communication' is understood as adequate mutual understanding of participants of the communication belonging to different national cultures.

\section{b) CCU Based Learning Activities in EFL Context}

Researchers conducted some studies on CCU based learning activities in EFL context with some findings as below:

1. Lee (2000) showed that teachers have to have an ability to mediate the local and target culture and in line with openmindness and sensitivity to cross-cultural differences, should be raised in EFL classrooms.

2. Cakir (2006) showed that firstly developing cultural awareness in the classroom is important for teachers help students distinguish between the cultural norms, beliefs, or habits of the majority within the speech community, secondly development of an awareness of sociocultural and sociolinguistic differences which might exist in the students' first and foreign language prevent unintended pragmatic failure and breakdown in communication and the last studying English does not change students' identity and students implement teachers' theories to use English well.

3. Dai (2011) found that teachers should facilitate students' learning materials by implementing cross-cultural based learning activity and connecting with students' interests.

In the field of pragmatic, apology function attracted more attentions than other speech acts (Brown, 1987 as cited in Raed \& Mohamad, 2016, p. 33). The following are the indicators for EFL students who are aware of apologies: 
1. EFL learners are able to realize and differentiate the use of appropriate realization pattern;

2. EFL learners have to be able to and aware of the intensification devices such as "very", "terribly", and "really" (Eslami Rasekh \& Mardani, 2010);

3. EFL learners are able to understand their positions. The recognition as apology makers toward the degree at the offence, the power of the addressee over the addressor, and the social distance(Brown \& Levinson, 1987);

4. EFL learners are able to maintain good relations between others (the participants of the speech) (Holmes, 1990);

5. EFL learners have to be able to understand and know the difference of expression "sorry" and "I apologize" and intensifiers like "very" and "really" (Olshtain \& Cohen (1983); Olshtain (1989);

6. EFL learners have to be able to interpret, give and respond in apologizing appropriately to build friendly relationships with native and non-native speakers especially when they encounter English speaking countries or working field (Wolfson, 1983).

Many researchers conducted studies to prove failure or success of awareness on speech acts functions from EFL students' perspectives, some studies can be summarized as follows:

1. Zhao \& Throssell (2011) found that Chinese EFL learners, even though possessing good mastery of English grammar and vocabulary, still fail to make use of appropriate speech in their communication with native speakers of English.

2. Wijayanto (2013) stated that Javanese learners of English commonly initiate refusals with an apology.

3. Zayed (2014) revealed that only one EFL teacher and one Jordanian EFL student in the first grade practiced the form 'an expression of an apology' particularly the word 'sorry; once.

4. Abolfathiasl and Abdullah (2015) Iranian EFL learners showed their consciousness-raising improved by performing and responding of making suggestions function of speech act.

5. Kurdghelashvili (2015) Georgian EFL students were failed in term of their knowledge regarding politeness strategies in 
English communication for the speech acts functions only use by the teacher not the students in the classroom interactions.

Reviewing related studies related to cross cultural understanding-based learning activities from ESL and EFL context and speech act awareness of EFL learners leads a gap from previous researches. On the other hands, there are alot of studies on cross cultural understanding-based learning activities viewed from sociolinguistic competence, while there are few of cross cultural understanding studies from pragmatic point of view, speech act awareness. Whereas the study of cross cultural understanding requires to be analyzed deeper from both perspectives in order to give a better understanding on this term and a factual implementation toward learners, EFL learners. Therefore, the novelty of this study gives an additional analysis toward cross cultural understanding-based learning activities from the perspective of speech act awareness by enhancing speech act awareness on apology of EFL learners. Not only reviews the implementation of cross cultural understandingbased learning activities in EFL context, this study also explain and describe to what extent CCU based learning activities contribute toward the EFL students' awareness of speech acts and why the teaching of cross cultural understanding raises the speech act awareness of EFL students. It suggests teachers, lecturers, learners especially EFL learners to be more aware while performing speech acts functions through CCU based learning activities since it is implemented by some constraints.

\section{RESEARCH METHOD}

Six English Department students (who already passed CCU course) were chosen from private university in Salatiga and state university in Surakarta, Solo. To collect considerable information and get reliable data, the study analyzed one questionnaire (Discourse Completion Task Questionnaire) DCTQ and one interview with twelve participants. Before conducting actual study, the questionnaire and the interview were piloted and validated.

Discourse completion task questionnaire is regarded as an effective research instrument (Beebe\&Cummings, 1996, p. 66 as 
cited in Raed and Mohammad, 2016, p. 34). In the present study, the DCTQ consisted of six parts: the first one contained about Cross Cultural Understanding, the second part contained about speech acts, the next part contained about speech acts awareness, the fourth part was about Cross Cultural Understanding and speech acts awareness, the fifth part was about two situations from apology functions and the last part contained about background information of the participants.

The interviews are conducted in the learners' mother tongue (Bahasa Indonesia) and English, although most respondents preferred to use English. Each interview lasted between 15 and 20 minutes. The interviews are semi-structured (Merriam, 1998, P. 73). All the interviews are audio-taped and later transcribed for further analysis. These transcripts are then analyzed according to predetermined similar categories found in the questionnaire namely CCU understanding, CCU based learning activities, types of speech acts, speech act awareness.

\section{FINDINGS AND DISCUSSION}

1. To what extent do CCU learning activities contribute toward EFL students' awareness on apology?

A. Group discussion for apology function as one of CCU learning activities viewed from communication strategies

Apology performed by EFL students from CCU learning activity showed that group discussion as the highest choice from the questionnaire and the interview done with them. Group discussion has $45 \%$ of other CCU learning activities, role play has $35 \%$, response journals has $10 \%$ and others like movie review, presentation and culture festival has $5 \%$. Then, the result was presented in the following chart and explanations were provided accordingly. 


\section{Edulangue Vol 1 (1) 2018}

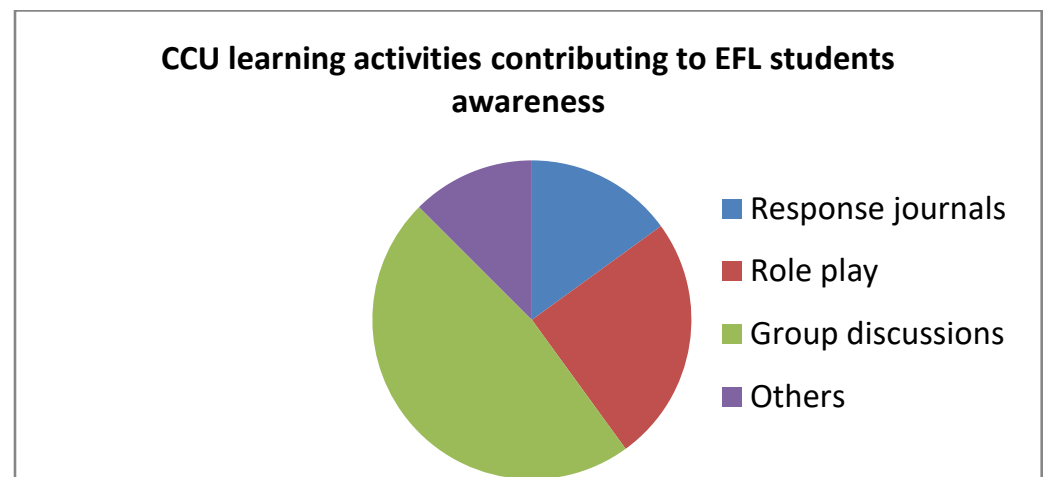

Chart 4.2 Types of CCU Learning Activities Contributing to EFL Students' Awareness.

Talking about group discussions, it can be developed in the language classroom for pragmatic development to be specific raising EFL students' awareness on apology function. Kasper (1997) identified two types of activities. First, activities can focus on raising students' pragmatic awareness, or second, on tasks which provide opportunities for student to actually practice communication.

In this case, EFL students are provided with CCU learning activity in form of group discussion which raises their awareness on those two functions. As a leading discussion, the lecturer gave a picture which showed people were queuing in a movie theater and one person felt that his leg was stepped by another person as below:

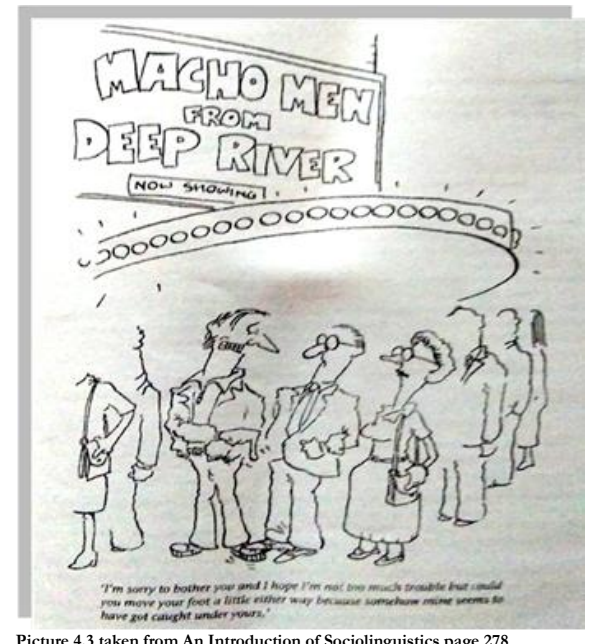


After that, they discussed together and were asked to make apology function in accordance with their own cultures seeing the fact that there were a lot of students from different ethnicities.

\section{Situation portrayed in the picture:}

There were people queuing for tickets of a movie titled MACHO MAN FROM DEEP RIVER. When these people queiung, a man accidentally stepped on other man foot. This man whose foot stepped said "I'm sorry to bother you and I hope I'm not too much trouble but could you move your foot a little either way because somehow mine seems to have got caught under yours."

\begin{tabular}{|c|c|c|c|c|c|}
\hline \multirow[b]{2}{*}{ Sentences } & \multicolumn{5}{|c|}{ Strategies used in apology speech act (by Oslhtain and Cohen) } \\
\hline & $\begin{array}{l}\text { An } \\
\text { intensified } \\
\text { expression } \\
\text { of apology }\end{array}$ & $\begin{array}{l}\text { An } \\
\text { expression / } \\
\text { acknowledge } \\
\text { ment of } \\
\text { responsibility }\end{array}$ & $\begin{array}{l}\text { An explanation } \\
\text { or account of } \\
\text { the situation }\end{array}$ & $\begin{array}{l}\text { An offer of } \\
\text { repair }\end{array}$ & $\begin{array}{l}\text { a promise of } \\
\text { non } \\
\text { reoccurrence }\end{array}$ \\
\hline $\begin{array}{l}\text { "I'm sorry } \\
\text { to bother } \\
\text { you and I } \\
\text { hope I'am } \\
\text { not too } \\
\text { much } \\
\text { trouble but } \\
\text { could you } \\
\text { move your } \\
\text { foot a little } \\
\text { either way } \\
\text { because } \\
\text { somehow } \\
\text { mine seems } \\
\text { to have got } \\
\text { caught } \\
\text { under yours. }\end{array}$ & $\begin{array}{l}\text { I'm sorry to } \\
\text { bother you } \\
\text { and I hope } \\
\text { I'am not too } \\
\text { much trouble }\end{array}$ & & $\begin{array}{l}\text { because somehow } \\
\text { mine seems to } \\
\text { have got caught } \\
\text { under yours. }\end{array}$ & & \\
\hline
\end{tabular}

1. In this context, because the action accidentally happened without the hearer's intention, there are no expressions or acknowledgement of responsibility, offer of repair and no promise of non-reoccurrence.

2. The expressions of apology used are:

a. I'm sorry to bother you

b. I hope I am not too much trouble

3. The explanation or account of the situation is:

a. incomplete sentence: 
...because somehow mine seems to have got caught under you

However, the researcher has one type of strategy used in analyzing one speech function: apology. The researcher applied Olshtain and Cohen (1983) apology speech act strategy. Therefore, group discussion which is used as leading activity to raise EFL students' awareness on apology function would be elaborated from one point of view: apology strategy.

\section{Strategies Used in Apology Function}

In this framework, there are five main strategies the researcher used for apology production including (1) expression of apology which itself contains three sub-strategies of expression regret, an offer of apology, and a request for forgiveness; (2) an explanation or account of the situation; (3) an acknowledgement of responsibility, which contains four sub-strategies of accepting blame, expressing self-deficiency, recognizing the other person as deserving apology, and expressing lack of intent; (4) an offer of repair; and (5) a promise of non-reoccurrence (Olshtain and Cohen, 1983 as cited in Tajeddin, Alemi \& Razzaghi, 2014, p. 9).

Situation 1: Imagine you are travelling on a bus. You put your bag in the rack, but it fell down and hit another passenger.

\begin{tabular}{|c|c|c|c|c|c|c|}
\hline \multirow[b]{2}{*}{$\begin{array}{l}\text { Informan } \\
t\end{array}$} & \multirow[b]{2}{*}{ Sentences } & \multicolumn{5}{|c|}{ Strategies used in apology speech act (by Oslhtain and Cohen) } \\
\hline & & $\begin{array}{l}\text { An } \\
\text { intensified } \\
\text { expression } \\
\text { of apology }\end{array}$ & $\begin{array}{l}\text { An } \\
\text { expression } \\
\text { / } \\
\text { acknowledg } \\
\text { ement of } \\
\text { responsibilit } \\
\text { y }\end{array}$ & $\begin{array}{l}\text { An } \\
\text { explanation } \\
\text { or account } \\
\text { of the } \\
\text { situation }\end{array}$ & $\begin{array}{l}\text { An offer of } \\
\text { repair }\end{array}$ & $\begin{array}{l}\text { a promise } \\
\text { of non } \\
\text { reoccurren } \\
\text { e }\end{array}$ \\
\hline TY & $\begin{array}{l}\text { Oh, I'm so } \\
\text { sorry! Are } \\
\text { you okay? } \\
\text { (because it } \\
\text { is a } \\
\text { spontaneo } \\
\text { us } \\
\text { incident) }\end{array}$ & $\begin{array}{l}\text { Oh, I'm so } \\
\text { sorry! }\end{array}$ & $\begin{array}{l}\text { Are you } \\
\text { okay? }\end{array}$ & & & \\
\hline WL & $\begin{array}{l}\text { My bad, I } \\
\text { am so } \\
\text { sorry. }\end{array}$ & $\begin{array}{l}\text { My bad, I } \\
\text { am so sorry. }\end{array}$ & & & & \\
\hline
\end{tabular}


Permatasari, et al., A Study of EFL ...

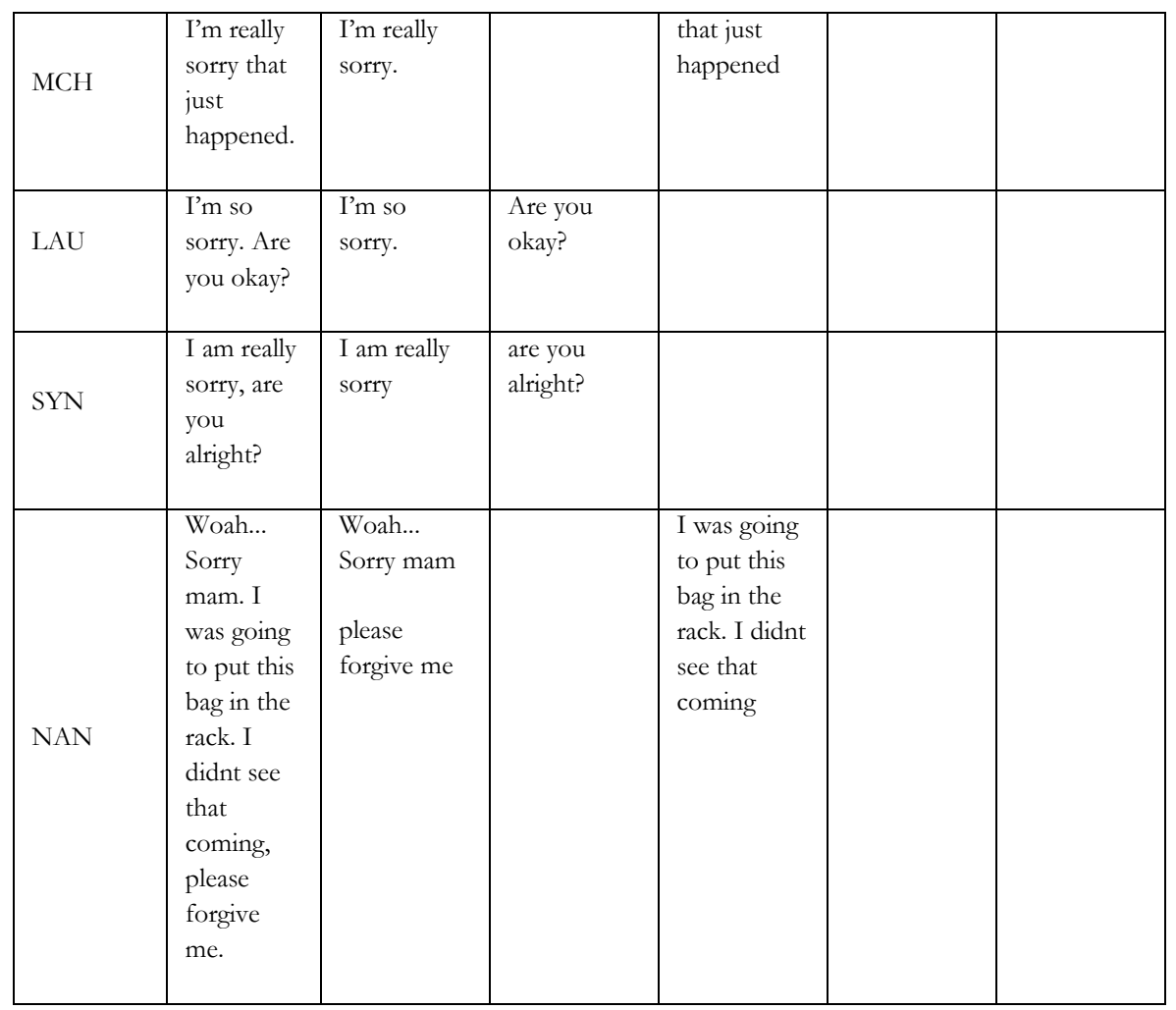

\section{ANALYSIS 1:}

1. In this context, because the action accidentally happened without the speaker's intention, there's no offer of repair and no promise of non reoccurrence.

2. The expressions of apology used are:

e. I'm so sorry

f. I'm really sorry

g. Sorry

h. Please forgive me

3. The intensified expressions used are:
d. $\mathrm{Oh}$
e. My bad
f. Woah

4. The expressions / acknowledgement of responsibility are

c. Are you okay?

d. Are you alright? 
These two sentences are polite expression to show the addressee that the addresser feels guilty about his or her careless action and cares about the addressee's condition.

5. The explanation or account of the situation is:

c. Complete sentence:

iii. I was going to put this bag in the rack.

iv. I didn't see that coming

d. Incomplete sentence:

ii. That just happened

Situation 2: Imagine you are the manager of a café. Today you have an interview with a student who wants to a job in the café. However, you are half an hour late for the interview because of a meeting. The student is waiting for you in the café.

\begin{tabular}{|c|c|c|c|c|c|c|}
\hline \multirow[b]{2}{*}{$\begin{array}{l}\text { Informa } \\
\text { nt }\end{array}$} & \multirow[b]{2}{*}{ Sentences } & \multicolumn{5}{|c|}{ Strategies used in apology speech act (by Oslhtain and Cohen) } \\
\hline & & $\begin{array}{l}\text { An } \\
\text { intensified } \\
\text { expression } \\
\text { of apology }\end{array}$ & $\begin{array}{l}\text { An } \\
\text { expression / } \\
\text { acknowledge } \\
\text { ment of } \\
\text { responsibility }\end{array}$ & $\begin{array}{l}\text { An } \\
\text { explanation } \\
\text { or account of } \\
\text { the situation }\end{array}$ & $\begin{array}{l}\text { An offer of } \\
\text { repair }\end{array}$ & $\begin{array}{l}\text { a promise } \\
\text { of non- } \\
\text { reoccurenc } \\
\text { e }\end{array}$ \\
\hline TY & $\begin{array}{l}\text { I'm } \\
\text { extremely } \\
\text { sorry for } \\
\text { making you } \\
\text { wait quite a } \\
\text { long time. } \\
\text { Thank you } \\
\text { for staying. }\end{array}$ & $\begin{array}{l}\text { I'm } \\
\text { extremely } \\
\text { sorry }\end{array}$ & $\begin{array}{l}\text { for making } \\
\text { you wait } \\
\text { quite a long } \\
\text { time. }\end{array}$ & $\begin{array}{l}\text { Thank you } \\
\text { for staying. }\end{array}$ & & \\
\hline WL & $\begin{array}{l}\text { I am sorry } \\
\text { for being } \\
\text { late. My } \\
\text { watch's } \\
\text { battery is } \\
\text { broken and } \\
\text { I have two } \\
\text { meetings } \\
\text { today. Can } \\
\text { we start } \\
\text { now? }\end{array}$ & I am sorry & for being late & $\begin{array}{l}\text { My watch's } \\
\text { battery is } \\
\text { broken and I } \\
\text { have two } \\
\text { meetings } \\
\text { today. }\end{array}$ & $\begin{array}{l}\text { Can we start } \\
\text { now? }\end{array}$ & \\
\hline $\mathrm{MCH}$ & $\begin{array}{l}\text { I do } \\
\text { apologize } \\
\text { for the } \\
\text { inconvenien } \\
\text { t. I had a } \\
\text { meeting } \\
\text { earlier that's } \\
\text { why I come } \\
\text { late. }\end{array}$ & $\begin{array}{l}\text { I do } \\
\text { apologize } \\
\text { for the } \\
\text { inconvenien } \\
\text { t. }\end{array}$ & $\begin{array}{l}\text { that's why I } \\
\text { come late. }\end{array}$ & $\begin{array}{l}\text { I had a } \\
\text { meeting } \\
\text { earlier }\end{array}$ & & \\
\hline LAU & $\begin{array}{l}\text { I'm sorry I } \\
\text { am late. Can }\end{array}$ & I'm sorry & I am late. & & $\begin{array}{l}\text { Can we start } \\
\text { now? }\end{array}$ & \\
\hline
\end{tabular}


Permatasari, et al., A Study of EFL ...

\begin{tabular}{|c|c|c|c|c|c|}
\hline & $\begin{array}{l}\text { we start } \\
\text { now? }\end{array}$ & & & & \\
\hline SYN & $\begin{array}{l}\text { I'm so sorry } \\
\text { I am late, I } \\
\text { had to } \\
\text { attend a } \\
\text { meeting. }\end{array}$ & I'm so sorry & I am late, & $\begin{array}{l}\text { I had to } \\
\text { attend a } \\
\text { meeting. }\end{array}$ & \\
\hline NAN & $\begin{array}{l}\text { I'm sorry I } \\
\text { was caught } \\
\text { up in the } \\
\text { traffic that's } \\
\text { why I really } \\
\text { late. So let's } \\
\text { start. }\end{array}$ & I'm sorry & $\begin{array}{l}\text { that's why I } \\
\text { really late. }\end{array}$ & $\begin{array}{l}\text { I was caught } \\
\text { up in the } \\
\text { traffic }\end{array}$ & $\begin{array}{l}\text { So let's } \\
\text { start. }\end{array}$ \\
\hline
\end{tabular}

\section{ANALYSIS 2:}

1. In this context, the addressers violate the punctuality in making an appointment with his or her candidate of worker. From the corpus gathered, while dealing in such context, some of the informants tried to defend themselves by explaining the situation. Some of them preferred not give any explanation.

2. All informants do not give a promise of non reoccurrence.

3. The expressions of apology used are:

iii. Sorry

iv. I do apologize

4. The expression / acknowledgement of responsibility are in the form of:

i. incomplete sentence:

a. for making you wait quite a long time

b. for being late

c. that's why I come late

d. that's why I really late

ii. complete sentence:

a. I am late

5. The explanation or account of the situation in the form of complete sentence:

a. Thank you for staying.

b. My watch's battery is broken and I have two meetings today.

c. I had a meeting earlier

d. I was caught up in the traffic

6. Three informants gave an offer of repair in the form of complete sentence: 
a. Can we start now?

b. Let's start now.

\section{B. Group discussions in teaching materials preparation: as topic oriented activity}

In preparing teaching materials, a lecturer must present an issue which attracts students' interests. This issue or related topic which is familiar with their background knowledge will lead them to positively engage and participate in the classroom. In this case, topics or issues in the sense of students' cultural norms like food, dances, custom, and songs from many ethnicities. Then, the lecturer's duty is to bring and adjust these students to the target culture. In dealing with the topics, EFL students prefer to do group discussion to discuss the cultural border between their own and the world of the target language in relation with speech acts function. Considering there are two knowledge that are required to be acquired by EFL students: linguistic and pragmatic knowledge, Watts' (2010), Alemi \& Tajeddin (2013), Jalilifar (2009) findings showed that EFL learners did not have sufficient pragmatic knowledge. The most common function EFL students use in daily life is apology which they lack of knowledge. Thus, group discussion: sharing ideas, experience with classmates will lead EFL students to understand the practices of apology function (Lave \& Wenger, 1991). The following will be the elaboration of two types of group discussion which enhance EFL learners' awareness of apology function.

First, politeness for apology became one topic for discussion. Knowing that TY, WL live in Indonesia, they seldom use apology pattern to NS or friends who speak English. They only speak or express the word sorry when they do something wrong whether he or she is older or younger than them for apology function. The recognition of social power gained when TY and WL discussed with their friends who live abroad or the NS lecturer who teach them.

I feel that I found it was quite difficult for me to adjust with it in the beginning because I used to say sorry a lot especially to people with higher social er (professor or teacher) and here, a single "I do apologizı enough. Because 
unlike in Indonesia, everything here is straight to the point (TY, 24/03/2017).

Group discussion with classmates who came from many countries like American, Italian, and Germany about apology function in term of politeness made TY more aware of addressing apology expression toward young, same age or even older people. Similar to TY, WL gained more understanding how to address apology function by doing discussion with the natives when she encountered CCU course.

Natives whom I speak to taught me about the difference use of I am sorry, I do apologize, I feel sorry about... for apology (WL, 28/08/2017).

WL regarded that by having discussion with the Natives as an effective way to raise EFL students' awareness on apology function. The natives face the real world and performing those two functions in their daily life. Thus, by having discussions with the natives teach WL how to express apology function and address it properly. Moreover, being linguistically polite involve speaking to people appropriately in the light of relationship between speaker and hearer. Making decisions about what is or is not considered polite in any community of practice therefore involves assessing social relationships along the dimensions of social distance or solidarity, and relative power or status (Laver, 1981, p. 285). Thus, gaining linguistic and pragmatic competence is required to understand and practice apology function well.

Second, culture festival as a form of cultural activity enhanced EFL learners' awareness on apology. Culture festival is one type of visible culture that is apparent to anyone and can be discussed and explained relatively easily (Hinkel, 2018, p. 5). Similarly, culture festival was chosen as one favorite activity which provided insights from EFL students to be a cultural sensitive person. When culture festival is held, EFL students had to pick one ethnicity from Indonesia or other countries and dress up like them. What is more attractive, they had to walk around the campus field and asked or discussed or even responded their classmates who wore the other costumes and prepared some situations of speech 
act functions. Likewise, LAU who loved culture festival as a leading discussion to raise her awareness toward apology function.

I would prefer to choose an activity which engage students' creativity and team-working like culture festival. We dressed up like people from different countries but we weren't allowed to dress up like Javanese people. Then, we did something interesting. We made conversation with certain situation and we listened to each other stories of our own costumes. (LAU, 25/10/2017).

The same idea came up from NAN about culture festival. He concluded that by participating in culture festival, he had no choice to work and gather with his classmates instead of doing individual working. Therefore, he gained a lot of experience, knew more about the use of speech act function and different cultural background of his classmates and realized that culture in the world is varied.

\section{Role Playing In Teaching Materials Preparation: As Authentic Materials Selection}

The second choice of CCU learning activities that contribute EFL students' awareness on apology is role playing. A lecturer should consider engaging activities instead of delivering the materials that keep the students in passive state. Therefore, role play, as an active teaching strategy, creates positive elements of enjoying learning process and gaining knowledge, when implemented successfully and selecting authentic materials (Erturk, 2015; McSharry\&Jones, 2000). In the same way, role play can enhance students' interests in learning the materials. The same idea came from AR who chose role play as the attractive CCU learning activity which is engaging and fun.

Role playing a certain culture is another fun activity because everyone in the class love performances, so it's an engaging yet fun activity for the students to grasp the issue especially when we talk about speech act functions like saying thanks, making apology (AR, 11/10/2017).

She felt that role play is a good way to grab students' attention to focus on speech act functions. By doing role play, EFL students directly practicece the dialogue from script-reading and there will be communication between the speaker and hearer. In 
the same time, they learn to express apology function and respond it as well. Thus, she thought that role play is the most effective way to enhance her skills and raise awareness on apologyy function.

Then, role play raises the link between the learning situation and the real world (Thiagarajan 2003 as cited in Greco 2009 p. 163). Similarly, role playing is viewed and has proven to be effective way to bridge students to their real world. Meaning that, when they do role playing they practice what they face in the real life. Moreover, RI has the same idea about role playing when she could share her understanding about other cultures with her classmates.

By doing a role play, we not only understand cultures from other countries but also put it into practice to share the knowledge to others. Role playing about Javanese vs Korean: apology. Javanese prefer saying a lot sorry everytime they make mistakes. Besides, Korean only remark for big mistakes then they say sorry. (RI, 28/08/2017).

Role playing on apology function also promote interaction among players: those who are in the dialogue (Van Ments 1989 as cited in Greco 2009 p. 163). When RI did role playing about Javanese vs Korean, she did interaction with her partner talking about what Javanese and Korean custom of asking for apology. Therefore, engagement among students who came from many ethnicities was increased through role playing (Clark \&Choi, 2005, Wishart et.al., 2007 as cited in Greco 2009 p. 163).

\section{CONCLUSION AND IMPLICATIONS}

Based on the analysis above, CCU learning activities which contributed toward EFL students' awareness on apology were group discussion and role playing. To begin with, the students found group discussion as learning strategy to make them aware of expressing apology function. By doing group discussion, EFL students gain more knowledge about others' cultures and in the same time they maintain good relations between others (Holmes, 1990). In addition, doing group discussion made EFL students recognize their position when they talk to each other: the social distance (the relationship between the speaker and the hearer), 
social power (the rank between the addressor and addressee) and imposition (description of the situation) (Brown \& Levinson, 1987; Searle, 1975). Likewise, EFL students should be aware of behavior, intonation pattern, choice of expression used which are appropriate in their own speech community with different cultural background (Peterson\&Coltrane, 2003; Flood, 2003). Hence, the success of making communication with both native or non native speakers is acquiring two kinds of competence: linguistic and pragmatic (Cortazzi \& Jin, 2008; Goh \& Kwah, 1997; Harvey, 1985; Rao, 2002; Leung, 2005).

For strategies used in apology, EFL students were able to differentiate the expressions of "sorry", "please forgive me" and intensifiers like "very" and "really" (Olshtain \& Cohen (1983); Olshtain (1989); Eslami Rasekh \& Mardani, 2010)). The findings on strategies used in apology showed that EFL students used an expression of apology like "sorry" with intesifiers like "so", "really", "please forgive me", and "I do apologize. Also, they stated an expression of responsibility like "are you okay?" or "are you alright?" (in complete sentence) and "....for making you wait quite long time", “....for being late”, “....that's why I come late”, “...that's why I really late (in incomplete sentence). Moreover, EFL students expressed an explanation on the situation by saying "I was going to put this bag in the rack", "I didn't see that coming", "thank you for staying.", "my watch battery is broken and I have two meetings today", "I had a meeting earlier", "I was caught up the traffic" (in complete sentence) and "...that just happenned" (in incomplete sentence). At last, some EFL students stated an offer of repair by saying "can we start now?" and "let's start now". However, none of students used a promise of non reoccurence. Thus, group discussion as one of cross cultural learning activity contributed toward EFL students' awareness on apology function in form of a leading activity which foster and enhance students' awareness by doing discussions among students with varies cultures and ethinicities in certain situations using certain speech acts in this case apology and its strategies.

In the second, group discussion as topic oriented activity was resulted in two findings. First, EFL students were discussed more on politeness for apology. They became more aware of 
addressing those two functions whether to same age, younger or older people. Besides, TY gained more knowledge about politeness when she met her classmates which came from different countries where English is as Foreign language. Similarly, discussion with the natives which WL did strengthen the way she communicate and address toward people she is going to talk. Then, discussion on culture festival created not only recognition of cultural and ethnicity varieties but also awareness of communicating through different situation using different speech functions.

Last of all, role playing as authentic material selection regarded to be second way of enhancing EFL students' awareness on apology. For instance AR and RI found that role playing was able to attract students' attention by creating the script of the situation, practising the script-reading and the existence of communication between the speaker and hearer of certain situations with apology function.

Language and culture are inseparable meaning that they cannot be separated and relate one to another. Thus, when teaching a foreign language cannot be separated from teaching its cultural and social norms. When it comes to EFL students' awareness on apology and request functions through Cross Cultural learning activities, it is a must for the lecturer to find the most attractive activities which engage, enhance, raise EFL students' interest and awareness. Hopefully, the findings of this study will help EFL lecturers to give more attention to students' pragmatic competence, raise their awareness on social cultural norms of speech acts realization in this case apology and request functions concerning politeness values are just as essential as acquiring linguistic competence.

\section{REFERENCES}

Abolfathiasl, H., \& Abdullah, A. N. (2015). Pragmatic consciousness-raising activities and EFL learners' speech act performance of 'making suggestions'. Journal of Language Teaching and Research, 6(2), 333-342. 
Austin, J. L. (1962). How to do things with words. Oxford: Clarendon Press.

Bardovi-Harlig, K. \& Hartford (1993). Learning the rules of academic talk: A longitudinal study of pragmatic change. Studies in Second Language Acquisition, 15, 279-304.

Bergman, M. L., \& Kasper, G. (1993). Perception and Performance in Native and Nonnative Apology. In G. Kasper \& S. Blum-Kulka (Eds.), Interlanguage Pragmatics, 82-107. Oxford: Oxford University Press.

Brown, P., \& Levinson, S. (1987). Politeness: Some universals in language usage. Cambridge: Cambridge University Press.

Cakir, I. (2006). Developing cultural awareness in foreign language teaching. Turkish Online Journal of Distance Education,7 (3), p. 154-161, ISSN 1302-6488.

Cohen, A. (2008). Teaching and assessing L2 pragmatics: What can we expect from learners? Language Teaching, 41, 213-235.

Cook, M. and A. J. Liddicoat. (2002). The development of comprehension in interlanguage pragmatics: The case of request strategies in English. Australian Review of Applied Linguistics, 25(1), 19-39.

Cortazzi, M., \& Jin, L. (2008). English teaching and learning in China. Language Teaching,29(02), 61-80.

Dai, Lili. (2011). Practical Techniques for Cultural-based Language Teaching in the EFL Classroom. Journal of Language Teaching and Research, 2(5), 1031-1036, ISSN 1798-4769, doi:10.4304/jltr.2.5.1031-1036.

Domakani, M.R., Hashemian, M., \& Mansoori, S. (2013). Pragmatic Awareness of the Request Speech Act in English as an Additional Language: Monolinguals or Bilinguals. RALS, 4(1), p. 88-109.

Ellis, R. (1994). The Studies of Second Language Acquisition. Oxford: Oxford University Press.

Enslen, Todd. Acquisition of Greetings, Requests, and Apologies by Japanese Students in an ESL vs. an EFL Environment, 連絡先： $=980-8576$ 宮城県仙台市青葉区川内41

東北大学高等教育開発推進センター enslen@he.tohoku.ac.jp pp.187-200. 
Permatasari, et al., A Study of EFL ...

Fadeeva and Kalinin. (2012). The Importance of Cross Cultural Understanding for ESL Students, УНИВЕРСИТЕТ им. В.И. ВЕРНААСКОГО, 4 (42), p. 144-151.

Fielding, M. (2006). Effective communication in organisations (3rd ed.). Cape Town: Juta \& Co. (Pty) Ltd.

Flood, J. (2003). Handbook of research on teaching the English language arts. Mahwah, New Jersey: Lawrence Erlbaum Associates, Inc., Publishers.

Gibbs, G. R., (2007). Analyzing qualitative data. In U. Flick (Ed). The Sage Qualitative Research Kit. London: Sage.

Goh, C., \& Kwah, P. F. (1997). Chinese ESL students' learning strategies: A look at frequency, proficiency and gender. Hong Kong Journal of Applied Linguistics, 2(1), 39-53.

Gumperz, J. J., \& Cook-Gumperz, J. (1982). Introduction: Language and the communication of social identity. Cambridge: Cambridge University Press.

Harvey, P. (1985). A lesson to be Learned: Chinese approaches to language learning. ELT Journal, 39(3), 7-9.

Holliday, A. (1994). Appropriate Methodology and Social Context. Cambridge University Press.

Hymes, D. (1975). Foundations in Sociolinguistics An Ethnographic approach. America: Weidner Associates, Inc., Cinnaminson, NJ.

Jiang, W. (2000). The Relationship Between Language and Culture. ELT Journal, 54(4), 328-334.

Kasper, G. (1996). Introduction: Pragmatics in SLA. Studies in Second Language Acquisition, 18, 145-148.

Kasper, G. (1997). Can pragmatic competence be taught? (Network \#6) [HTML document]. Honolulu HI: University of Hawaii at Manoa, Second Language Teaching and Curriculum Center. Retrieved Kasper, G. and Rose, K. (2002. Pragmatic Development in a Second Language. Malden: Blackwell Publishing.

Krippendorff, K. (2004). Content analysis: An introduction to its methodology (2nd ed.). Thousand Oaks: Sage. 
Kurdghelashvili, T. (2015). Speech Acts and Politeness Strategies in an EFL Classroom in Georgia, World Academy of Science Engineering and Technology, 9(1), p.306-309.

Lee, P. (1998). Cross-cultural Awareness Raising in TEFL Pre-service Preparation Courses. MA dissertation in Applied Linguistics, the University of Birmingham.

Lee, P. (2000). Cross-cultural Awareness Raising in TEFL Preservice Preparation Courses. 5(1), p. 17-36.

Leung, C. (2005). Convivial communication: recontextualizing communicative competence. International Journal of Applied Linguistics, 15(2), 119-144.

Mackey, A., \& Gass, S. (2005). Second language research: Methodology and design. Mahwah, NJ: Lawrence Erlbaum.

Mayring, Philipp (2000a, June). Qualitative content analysis [28 paragraphs]. Forum Qualitative Sozialforschung / Forum: Qualitative Social Research [On-line Journal], 1(2), Art. 20. Available at: http://www.qualitative-research.net/fqstexte/2-00/2-00mayring-e.htm [Date of access: October 5, 2004].

Mayring, Philipp (2002). Einführung in die qualitative Sozialforschung, Eine Anleitung zu qualitativem Denken (5th ed.). Weinheim: Beltz.

Mizne. C. A. (1997). Teaching Sociolinguistic Competence in the ESL Classroom: A College Scholars Project. Retrieved March 22, 2017 in http://trace.tennessee.edu/cgi/viewcontent. cgi?article $=101$ 9\&context=utk_interstp2

National Standards in Foreign Language Education Project. (1996). Standards for foreign language learning in the 21st century. Yonkers, NY: Author.

Olshtain, E., \& Cohen, A. (1983). Apology: A speech act set. Sociolinguistics and language acquisition, 18-35.

Peterson, E., \& Coltrane, B. (2003). Culture in second language teaching [Electronic Version]. Center for Applied Linguistics. Retrieved March 22, 2017 from http://www.cal.org/resources/Digest/0309peterson.html

Porter, R. E., \& NANovar, L. A. (1991). Basic principles of intercultural communication. In L. A. NANo-var \& R. E. 
Permatasari, et al., A Study of EFL ...

Porter (Eds.), Intercultural communication: A reader. Boston, MA: Wadsworth Cengage Learning.

Qorina, Dwi. (2012).Realization Of Apology Strategies By English Department Studentsof Pekalongan University Language, Circle Journal Of Language And Literature, 7 (1), 93-105.

Rao, Z. (2002). Chinese students' perceptions of communicative and noncommunicative activities in EFL classroom. System, 30(1), 85-105.

Robinson, G. L. N. (1985). Culture Bound. Cambridge University Press.

Rose, K. R. (1999). Teachers and students learning about requests in Hong Kong. Culture in second language teaching and learning. Ed. E. Hinkel. Cambridge: Cambridge University Press. 167-180.

Sardi, C. (2002). On the Relationship between Culture and ELT. Studies About Languages (3), 101-107.

Searle, J. R. (1969). Speech acts: An essay in the philosophy of language. Cambridge, UK: Cambridge University Press

Seliger, H. W., \& Shohamy, E. (1989). Second language research methods. Oxford: Oxford University Press.

Sifianou, M. (1999). Politeness phenomena in England and Greece. A crosscultural perspective. Oxford: Oxford University Press.

Smith, E. L. (1985). What is the Difference and What Difference Does the Difference Make. In Forum vol.22.

Tanaka, N. (1991). An investigation of apology: Japanese in comparison with Australian. Maikai Daigaku Gaikokugo Gakubu Ronsbu, 4, 35-53.

Titscher, Stefan, Meyer, Michael, Wodak, Ruth, \& Vetter, Eva (2000). Methods of text and discourse analysis (Bryan Jenner, Trans.). London: Sage.

Trosborg, A. (1995). Interlanguage pragmatics: Requests, complaints, and apologies. Berlin: Mouton de Gruyter.

Wijayanto, A. (2013). The Emergence of the Javanese Sopan and Santun (Politeness) on the Refusal Strategies Used by Javanese Learners of English, The Internet Journal Language, Culture and Society, 36, 34-47. Retrieved from http:/ /aaref.com.au/en/publications/journal/ 
Wolfson, N., Marmor, T., \& Jones, S. (1989). Problems in the comparison of speech acts across cultures. In S. Blum-Kulka, J. House \& G. Kasper (Eds.), Cross-cultural pragmatics (pp. 174-196). Norwood, NJ: Albex.

Yin, Robert K. (2003). Case study research, design and methods (3rd ed., vol. 5). Thousand Oaks: Sage.

Youssef, H. Z. (2009). The Relationship Between Cross-Culture Communication Activities and Student Motivation in Studying Second Language. Retrieved March, 22, 2017 from http:/ / files.eric.ed.gov/ fulltext/ED511897.pdf

Zacharias, N. (2012). EFL Students' Understanding of Their Multilingual English Identities, Electronic Journal of Foreign Language Teaching, 9 (2), 233-244.

Zayed, M. (2014). Jordanian EFL teachers' and students' practice of speech acts in the classroom. International Journal on Studies in English Language and Literature (IJSELL), 2(5), 1-10.

Zhao, Y., \& Throssell, P. (2011). Speech Act Theory and Its Application to EFL Teaching in China. The International Journal - Language Society and Culture, 32, 88-95. Retrieved from www.educ.utas.edu.au/users/tle/JOURNAL/ 